\title{
Penggunaan Ventilatory Ratio dan Alveolar Dead Space Fraction sebagai Prediktor Mortalitas pada Pasien COVID-19 dengan Acute Respiratory Distress Syndrome
}

\author{
Muh. Kemal Putra, Arie Utariani, Christrijogo Soemartono, Bambang Pujo Semedi, Hardiono \\ Departemen Anestesi dan Terapi Intensif Fakultas Kedokteran Universitas Airlangga \\ RSUD Dr Soetomo Surabaya
}

\begin{abstract}
Abstrak
Pada pasien COVID-19 dengan ARDS terjadi gangguan oksigenasi dan ventilasi. Menurut kriteria Berlin ARDS, oksigenasi diukur dengan $\mathrm{PaO}_{2} / \mathrm{FiO}_{2}$, namun tidak mengukur ventilasi alveolar yang diukur dengan dead space yang dapat terjadi akibat kondisi, seperti kerusakan endotel, mikrotrombus, dan penggunaan ventilator yang berlebih. Tujuan penelitian ini menganalisis penggunaan ventilatory ratio (VR) dan dead space fraction (Vd/Vt) sebagai prediktor mortalitas pasien COVID-19 ARDS. Penelitian ini adalah analitik kohort retrospektif. Data dikumpulkan dari rekam medik pasien COVID-19 yang dirawat di RIK RSUD Dr. Soetomo periode Juni-September 2020 dengan teknik total sampling terhadap subjek yang memenuhi kriteria inklusi dan tidak termasuk eksklusi. Data yang dikumpulkan adalah nilai VR dan Vd/Vt (diambil dari data laboratorium), kondisi klinis pasien dan pengaturan ventilator 24 jam pertama setelah terintubasi. Penelitian ini didapatkan 77 dari 80 subjek yang memenuhi kriteria. Nilai VR berhubungan dengan mortalitas secara signifikan dengan nilai p 0,001; cut off 1,84; sensitivitas 84,2\%; spesifisitas 85\%; RR 30,22; CI 95\%: 7,31-124,89. Vd/Vt dan mortalitas menunjukkan hubungan yang signifikan terhadap mortalitas dengan nilai p 0.001. Uji analisis Spearman VR dengan Vd/Vt didapatkan hasil korelasi yang kuat dengan koefisien korelasi 0,704 dan p 0,001. Simpulan, nilai VR dan Vd/Vt dapat digunakan sebagai prediktor mortalitas pasien COVID-19 dengan ARDS dan keduanya mempunyai korelasi yang kuat. VR dapat menggantikan Vd/ Vt.
\end{abstract}

Kata kunci: ARDS, COVID-19, dead space fraction, mortalitas, ventilatory ratio

\section{Use of Ventilatory Ratio and Alveolar Dead Space Fraction as Predictorz of Mortality in Covid-19 Patients with Acute Respiratory Distress Syndrome}

\begin{abstract}
COVID-19 with ARDS experience impaired oxygenation and ventilation. In Berlin ARDS criteria, oxygenation is measured by $\mathrm{PaO}_{2} / \mathrm{FiO}_{2}$, but does not measure alveolar ventilation, which is measured through the dead space produced in this conditions, such as endothelial damage, microthrombus, and excessive use of entilator. The purpose of this study was to analyze the use of ventilatory ratio (VR) and dead space fraction (Vd/Vt) as predictors of mortality in patients with COVID-19 ARDS. This study was a retrospective cohort analytic study one medical records of COVID-19 patients treated in an inpatient unit of a referral hospital in Indonesia. The ethical clearance was obtained from the Health Research Ethics Committee of Dr. Soetomo Hospital, Indonesia. Data were collected through total sampling of medical records that met the inclusion and exclusion criteria. The VR and Vd/Vt scores were collected from the laboratory data, patient clinical condition, and ventilator setting 24 hours after intubation. Of all medical records screened, 77 out of 80 samples met the criteria. VR was significantly associated with mortality with a p value of 0.001 (cut-off point:1.84, sensitivity: 84.2\%, specificity: 85\%, RR: 30.22, and 95\%, CI: 7.31-124.89). Similarly, Vd/Vt and mortality showed a significant relationship with mortality with a p value of 0.001 (cut-off: 0.25 , sensitivity: 85\%, specificity: 86\%, RR: 34.71, 95\% CI: 8.24-146.05). The Spearman analysis test between VR and Vd/Vt showed a strong correlation with a correlation coefficient of 0,704 and p 0,001 . Thus, VR and Vd/Vt can be used as predictors of mortality in COVID-19 patients with ARDS and because both have a strong correlation. VR can also substitute Vd/Vt.
\end{abstract}

Key words: ARDS, COVID-19, dead space fraction, mortality, ventilatory ratio

Korespondensi: Muh. Kemal Putra, dr., SpAn, Departemen Anestesi dan Terapi Intensif Fakultas Kedokteran Universitas Airlangga/RSUD Dr. Soetomo Surabaya, Jl. Mayjen Prof. Dr. Moestopo 6-8, Surabaya, Tlpn 031 5501504, Email kemalputra2789@gmail.com 


\section{Pendahuluan}

Kota Wuhan, Provinsi Hubei, Tiongkok melaporkan kasus pneumonia misterius yang tidak diketahui penyebabnya pada tanggal 31 Desember 2019. Dalam 3 hari kasus tersebut berjumlah 44 pasien dan terus bertambah hingga saat ini berjumlah lebih dari 4,5 juta kasus di seluruh dunia. ${ }^{1}$ Sampel isolat pasien menunjukkan infeksi coronavirus, jenis betacoronavirus tipe baru. Pada tanggal 11 Februari 2020, World Health Organization (WHO) memberi nama virus baru tersebut severe acute respiratory syndrome coronavirus-2 (SARS-CoV-2) dan nama penyakitnya sebagai coronavirus disease 2019 (COVID-19). ${ }^{2}$

Infeksi SARS-CoV-2 memberikan spektrum gejala yang bervariasi, mulai dari tanpa gejala, gejala ringan, pneumonia, pneumonia berat, ARDS, sepsis, hingga syok septik. Dari studi 138 pasien yang terkonfirmasi COVID-19 sekitar 102 pasien $(73,9 \%)$ menunjukkan gejala ringan atau sedang, 36 pasien $(26,1 \%)$ menunjukkan gejala berat yang membutuhkan perawatan di ICU, dan sebanyak 17 pasien dengan gejala berat tersebut jatuh dalam keadaan kritis yang membutuhkan bantuan ventilator mekanik. ${ }^{3}$ Pada kasus berat, perburukan pneumonia COVID-19 terjadi secara cepat dan progresif dan menyebabkan acute respiratory distress syndrome (ARDS). Pada penelitian terhadap 201 pasien dengan pneumonia COVID-19 yang meneliti faktor risiko angka kejadian ARDS dan mortalitas pada pasien COVID-19 didapatkan angka kejadian ARDS sebanyak 41,8\% dengan mortalitas sebesar $52,4 \%{ }^{4}$

Pertukaran gas terdiri atas oksigenasi dan ventilasi. Oksigenasi dikuantifikasi oleh rasio $\mathrm{PaO}_{2} / \mathrm{FiO}_{2}$ dan metode ini telah diterima secara luas, terutama sejak dipublikasinya kriteria Berlin ARDS. Namun, kriteria Berlin tidak termasuk informasi patofisiologis tambahan tentang ARDS, seperti ventilasi alveolar, yang diukur dengan dead space paru yang dapat terjadi akibat beberapa kondisi, seperti kerusakan endotel, mikrotrombus, gangguan obstruksi aliran darah paru, dan penggunaan ventilator mekanik yang berlebih. ${ }^{5}$
Dead space merupakan komponen ventilasi yang terbuang karena oksigen $\left(\mathrm{O}_{2}\right)$ tidak berpartisipasi dalam pertukaran gas (perfusi). Peningkatan dead space menggambarkan ketidakmapuan paru untuk mengeleminasi karbon dioksida $\left(\mathrm{CO}_{2}\right) \cdot{ }^{6}$ Dalam praktik klinis, gangguan eliminasi $\mathrm{CO}_{2}$ dapat diamati dari peningkatan $\mathrm{PaCO}_{2}$ (hiperkapnia), penurunan minute ventilation atau gangguan keduanya. Hiperkapnia sering ditemukan pada pasien COVID-19 dengan ARDS yang memberikan kesan dead space yang tinggi dan inadekuasi ventilasi. ${ }^{7}$ Dengan demikian, diperlukan suatu parameter untuk mengukur adekuat tidaknya ventilasi dan memberikan estimasi besaran dead space. Dead space fraction (Vd/Vt) adalah rasio volume ruang mati terhadap volume tidal. Rasio ini menunjukkan area di paru yang menerima ventilasi yang memadai, tetapi aliran darah paru tidak memadai atau tidak ada. Ventilasi pada alveoli ini disebut sebagai "ventilasi terbuang" atau ventilasi ruang mati. Nilai normal Vd/Vt kurang dari 0,3 , tetapi dapat meningkat menjadi 0,6 atau lebih bila ada peningkatan ventilasi ruang mati. Peningkatan Vd/ Vt terjadi dengan gagal napas akut, penurunan curah jantung, dan emboli paru. Pengukuran dead space fraction pertama kali diperkenalkan oleh Bohr. ${ }^{8}$ Namun, pengukuran tersebut tidak digunakan secara rutin dalam praktik klinis karena penggunaan kantong douglas yang rumit dan tidak praktis untuk mengukur $\mathrm{PECO}_{2}$. Penelitian pada 170 pasien mengenai dead space, D-dimer, dan emboli pulmonal, Kline dkk. ${ }^{9}$ memodifikasi persamaan Bohr dengan menggunakan $\mathrm{ETCO}_{2}$ sebagai pengganti $\mathrm{PECO}_{2}$.

Ventilatory ratio (VR) adalah indeks gangguan efisiensi ventilasi yang sederhana dan memungkinkan penilaian yang cepat terhadap adekuat tidaknya ventilasi serta berkorelasi baik dengan dead space pada pasien dengan ARDS. ${ }^{10}$ VR menjadi pemeriksaan yang lebih praktis dalam praktik sehari-hari dibanding dengan $\mathrm{Vd} / \mathrm{Vt}$.

Berdasar atas temuan tersebut, penelitian ini dilakukan untuk menganalisis penggunaan VR dan Vd/Vt sebagai prediktor mortalitas pasien COVID-19 dengan ARDS. 


\section{Subjek dan Metode}

Penelitian ini merupakan penelitian observasional analitik dengan desain retroprospektif yang dilakukan mulai bulan Juni 2020 hingga September 2020 di Ruang Isolasi Khusus (RIK) RSUD Dr. Soetomo setelah mendapatkan persetujuan dari Komite Etik Rumah Sakit (Nomor 0009/KEPK/VI/2020) dengan subjek penelitian ini adalah pasien COVID-19 yang terkonfirmasi dengan PCR spesimen swab tenggorokan dan kriteria inklusi adalah pasien dewasa (berusia di atas 17 tahun) dan pasien COVID-19 dengan komplikasi ARDS sesuai dengan definisi Berlin dengan bantuan napas ventilasi mekanik/ intubasi yang. Kriteria eksklusi pada penelitian ini adalah data penelitian yang tidak lengkap.

Teknik pengumpulan sampel menggunakan teknik total sampling. Data didapatkan dari rekam medik pasien COVID-19 dengan ARDS yang terintubasi yang masuk di ruang isolasi khusus RSUD Dr. Soetomo Surabaya selama periode penelitian. Data klinis seperti variabel hemodinamik, pengaturan ventilator, laboratorium, perhitungan VR dan Vd/Vt pasien COVID-19 dengan ARDS 24 jam pasca intubasi dicatat dalam lembar pengumpulan data dan selanjutnya dianalisis.

Data yang dikumpulkan dianalisis menggunakan uji korelasi Pearson untuk distribusi data normal, Spearman untuk distribusi data tidak normal, dan uji regresi logistik. Cut-off point, digunakan uji ROC, chi-
Tabel 1 Karakteristik Umum Subjek Penelitian

\begin{tabular}{lcc}
\hline Data Demografi & n= 77 & $\begin{array}{c}\text { Persentase } \\
\text { (\%) }\end{array}$ \\
\hline Jenis kelamin & & \\
Laki-laki & 54 & 70 \\
Perempuan & 23 & 30 \\
Usia (tahun) & & \\
18-20 & 0 & 0 \\
$21-30$ & 6 & 8 \\
$31-40$ & 10 & 13 \\
41-50 & 22 & 29 \\
$51-60$ & 30 & 39 \\
61-70 & 8 & 10 \\
$71-80$ & 1 & 1 \\
BMI (kg/m ${ }^{2}$ ) & & \\
Underweight & 1 & 1 \\
Normal & 32 & 42 \\
Overweight & 26 & 34 \\
Obesitas & 18 & 23 \\
Komorbiditas & & \\
Ada & 65 & 84 \\
Tidak ada & 12 & 16 \\
Derajat ARDS & & 6 \\
Ringan & 5 & 39 \\
Sedang & 30 & 55 \\
Berat & 42 & \\
\hline & & \\
\hline
\end{tabular}

square untuk menentukan sensitivitas dan spesifisitas. Data diolah dengan menggunakan program statistical package for the social sciences (SPSS) versi 21.0.

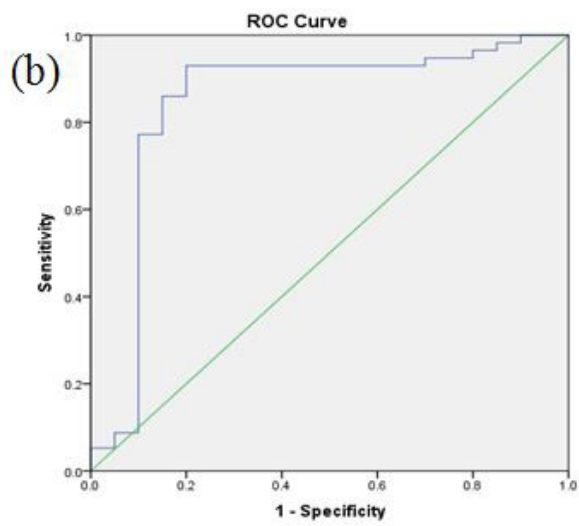

Gambar 1 (a) Grafik Analisis ROC VR. (b) Grafik Analisis ROC Vd/Vt 
Tabel 2 Analisis Bivariat Subjek Penelitian

\begin{tabular}{|c|c|c|c|}
\hline Karakteristik & Hidup & Meninggal & Nilai $p$ \\
\hline Usia, tahun & $48,95 \pm 8,39$ & $48,67 \pm 11,75$ & 0,920 \\
\hline Jenis kelamin & & & 0,254 \\
\hline Laki-laki & $12(60)$ & $42(74)$ & \\
\hline Perempuan & $8(40)$ & $15(26)$ & \\
\hline BMI, $\mathrm{kg} / \mathrm{m}^{2}$ & $23,51 \pm 3,50$ & $28,54 \pm 6,61$ & 0,004 \\
\hline Komorbiditas & & & 0,047 \\
\hline Ada & $14(70)$ & $51(90)$ & \\
\hline Tidak ada & $6(30)$ & $6(10)$ & \\
\hline Komplians, $\mathrm{mL} / \mathrm{cmH}_{2} \mathrm{O}$ & $28,57 \pm 13,32$ & $25,41 \pm 6,88$ & 0,189 \\
\hline $\begin{array}{l}\text { Derajat ARDS } \\
\mathrm{PaCO}_{2,} \mathrm{mmHg}\end{array}$ & $\begin{array}{c}153,56 \pm 52,85 \\
52,41 \pm 18,70\end{array}$ & $\begin{array}{l}93,65 \pm 30,98 \\
55.37 \pm 12,95\end{array}$ & $\begin{array}{l}0,001 \\
0,434\end{array}$ \\
\hline $\mathrm{ETCO}_{2}, \mathrm{mmHg}$ & $38,41 \pm 6,43$ & $35,06 \pm 8,72$ & 0,127 \\
\hline Ventilasi semenit, $\mathrm{mL} / \mathrm{mnt}$ & $9,29 \pm 2,2$ & $9,52 \pm 1,57$ & 0,597 \\
\hline $\begin{array}{l}\text { Ventilatory ratio (VR) } \\
\text { Vd/Vt } \\
\text { Parameter laboratorium }\end{array}$ & $\begin{array}{l}20(26) \\
20(26)\end{array}$ & $\begin{array}{l}57(74) \\
57(74)\end{array}$ & $\begin{array}{l}0,001 \\
0,001\end{array}$ \\
\hline Hemoglobin, $\mathrm{g} / \mathrm{dL}$ & $12,42 \pm 2,07$ & $13,39 \pm 1,99$ & 0,074 \\
\hline Leukosit, $10^{3} / \mu \mathrm{L}$ & $15,97 \pm 13,75$ & $15,31 \pm 7,87$ & 0,790 \\
\hline Platelet, $10^{3} / \mu \mathrm{L}$ & $308,75 \pm 132,89$ & $275,31 \pm 110,46$ & 0,271 \\
\hline BUN, mg/dL & $21,70 \pm 17,77$ & $28,04 \pm 28,48$ & 0,361 \\
\hline Kreatinin, mEq/L & $1,50 \pm 1,71$ & $2,67 \pm 6,39$ & 0,480 \\
\hline Sodium, mmol/L & $140,10 \pm 4,96$ & $141,74 \pm 7,30$ & 0,353 \\
\hline Klorida, mmol/L & $100,45 \pm 5,04$ & $102,22 \pm 5,79$ & 0,227 \\
\hline SGOT, $\mu / L$ & $70,05 \pm 37,70$ & $105,85 \pm 155,41$ & 0,321 \\
\hline SGPT, $\mu / L$ & $65,15 \pm 41,72$ & $90,40 \pm 139,36$ & 0,459 \\
\hline Albumin, g/dL & $2,99 \pm 0,33$ & $3,01 \pm 0,29$ & 0,839 \\
\hline Glukosa, mg/dL & $174,30 \pm 79,75$ & $190,19 \pm 84,09$ & 0,459 \\
\hline Laktat, mmol/L & $1,92 \pm 0,69$ & $4,22 \pm 1,53$ & 0,987 \\
\hline CRP, mg/L & $10,19 \pm 6.66$ & $21,41 \pm 43,26$ & 0,114 \\
\hline PCT, ng/mL & $6,97 \pm 19,72$ & $4,20 \pm 14,52$ & 0,512 \\
\hline D-dimer, ng/mL & $6394,00 \pm 9422,97$ & $5380,72 \pm 8897,69$ & 0,663 \\
\hline PT, detik & $12,37 \pm 2,42$ & $12,48 \pm 4,28$ & 0,916 \\
\hline aPTT, detik & $32,46 \pm 14,18$ & $36,63 \pm 17,43$ & 0,341 \\
\hline
\end{tabular}

Keterangan: Analisis bivariat menggunakan uji regresi logistik, signifikan bila nilai $p<0,05$

\section{Hasil}

Pada penelitian ini didapatkan 77 subjek yang memenuhi kriteria inklusi dan tidak termasuk kriteria eksklusi. Karakteristik umum subjek penelitian didapatkan bahwa mayoritas subjek berjenis kelamin laki-laki (70\%), berusia 5160 tahun (39\%), BMI normal (42\%), memiliki komorbiditas (84\%), dan mengalami ARDS derajat berat (55\%). (Tabel 1). 
Tabel 3 Analisis Analisis Sensitivitas, Spesifisitas, dan Cut-off

\begin{tabular}{lcccc}
\hline \multicolumn{1}{r}{ Variabel } & Cut Off & Sensitivitas (\%) & Spesifisitas (\%) & Nilai $\boldsymbol{p}$ \\
\hline $\mathrm{VR}$ & 1,84 & 84,2 & 85 & 0,001 \\
$\mathrm{Vd} / \mathrm{Vt}$ & 0,25 & 86 & 85 & 0,001 \\
\hline
\end{tabular}

Keterangan: Uji chi-square, signifikan bila nilai $\mathrm{p}<0,05$

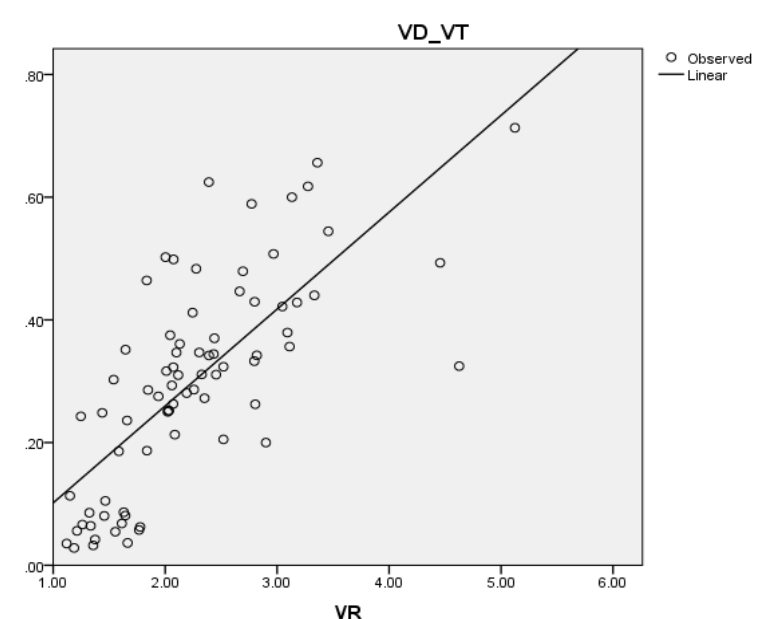

Gambar 2 VR vs Vd/Vt, Spearman's $r h o=0,771$; $\mathrm{p}<\mathbf{0 , 0 0 1}$

Karakteristik subjek penelitian dilakukan analisis bivariat untuk menentukan apakah tiap-tiap karakter dapat memengaruhi mortalitas dan dikatakan signifikan bila nilai $\mathrm{p}<0,05$. Adapun faktor yang signifikan memengaruhi mortalitas berdasar atas hasil analisis bivariat adalah BMI, komorbiditas, derajat ARDS, ventilatory ratio, dead space fraction (Tabel 2).

Analisis receiver operating characteristic (ROC) dilakukan terhadap variabel penelitian VR dan Vd/Vt. Berdasar atas hasil uji ROC, didapatkan area under curve (AUC) untuk tiaptiap faktor, yakni VR $(0,82)$, Vd/Vt $(0,85)$.

Dari hasil uji analisis variabel VR dan Vd/ Vt terhadap mortalitas didapatkan nilai cutoff, sensitivitas, dan spesifisitas. VR memiliki nilai cut-off 1,84 (p 0,001) dengan sensitivitas $84,2 \%$, spesifisitas $85 \%$. Vd/Vt memiliki nilai cut-off 0,25 (p 0,001) dengan sensitivitas $86 \%$ dan spesifisitas 85\% (Tabel 5).

Pada penelitian ini ditemukan korelasi yang kuat antara VR dan Vd/Vt berdasar atas uji korelasi Spearman dengan koefisien korelasi
0,77 dan nilai $\mathrm{p}<0,001$ (Gambar 2).

\section{Pembahasan}

Pada penelitian ini total pasien COVID-19 dengan ARDS di ruang isolasi khusus selama periode Juni-September 2020 didapatkan sebanyak 80 pasien, namun 3 pasien tidak memenuhi kriteria ARDS Berlin karena memiliki rasio $\mathrm{PaO}_{2} / \mathrm{FiO}_{2}>300$. Jumlah sampel yang memenuhi kriteria inklusi adalah 77 subjek.

Pada karakteristik pasien dapatkan beberapa variabel secara signifikan berpengaruh terhadap mortalitas pasien COVID-19 dengan ARD, yaitu derajat ARDS ( $\mathrm{p}<0,001)$, IMT ( $\mathrm{p} 0,004)$, komorbiditas ( $\mathrm{p}$ $0,047)$.

Pada penelitian ini derajat ARDS signifikan meningkatkan mortalitas sesuai dengan derajat berat ARDS. Pada pasien COVID-19 dengan ARDS berat didapatkan 42 subjek (74\%) meninggal. Penelitian yang sama mengemukakan bahwa COVID-19 dengan ARDS memiliki luaran yang lebih buruk dibanding dengan ARDS karena penyebab lain. Lama perawatan ICU dan mortalitas pada ARDS klasik adalah 35\% (95\% CI, 33,3-37,2\%) dan 40\% (95\% CI, 38,1-42,1\%). Mortalitas pada pasien COVID-19 dengan ARDS dengan perawatan ICU berkisar 26$61,5 \%$ dan pada pasien yang menggunakan ventilator, mortalitas dapat berkisar antara 65,7\% hingga 94\%. ${ }^{11}$ Pada penelitian ARDS klasik didapatkan etiologi ARDS, antara lain pneumonia sebanyak 1.794 (59,4\%), sepsis ekstrapulmonal sebanyak 484 (16\%), aspirasi pneumonia sebanyak $430(14,2 \%)$, syok nonkardiogenik sebanyak 226 (7,5\%), trauma sebanyak $127(4,2)$, transfusi darah sebanyak $118(3,9)$, kontusio pulmonum 
sebanyak $97(3,2 \%)$, Inhalasi gas beracun sebanyak $72(2,3 \%)$, overdosis obat sebanyak $56(1,9 \%)$, luka bakar sebanyak $41(1,4 \%)$, vaskulitis pulmonum sebanyak $9(0,3 \%)$, drowning sebanyak $2(0,1 \%)$. ARDS memiliki angka kematian yang tinggi pada penyebab di atas meskipun telah ada kemajuan dalam perawatan suportif. Terdapat peningkatan mortalitas yang signifikan dengan setiap peningkatan kategori derajat berat ARDS. Secara keseluruhan, $40 \%$ pasien ARDS meninggal selama perawatan. ${ }^{12}$

Pada penelitianini didapatkan bahwa pasien dengan malnutrisi signifikan meningkatkan mortalitas pada pasien COVID-19. Hal yang sama ditemukan pada penelitian sebelumnya bahwa obesitas meningkatkan risiko rawat inap, masuk ICU, penggunaan ventilator, dan mortalitas pada pasien dengan COVID-19. Obesitas meningkatkan risiko beberapa morbiditas yang umum seperti diabetes melitus, penyakit kardiovaskular, kanker, dan fatty liver non-alkoholik. Komorbiditas yang ada dianggap meningkatkan kemungkinan gejala yang berat akibat COVID-19. Jaringan adiposa yang berlebihan termasuk lemak ektopik dapat berfungsi sebagai reservoir untuk angiotensin-converting enzyme 2 (ACE2) seperti virus korona, virus influenza $A$, dan Microbacterium tuberkulosis. Dari penjelasan diatas, kombinasi disfungsi imun dan metabolik yang dimediasi jaringan adiposa mungkin memainkan peran kunci dalam jalur patofisiologis yang menyebabkan obesitas dan memengaruhi prognosis COVID-19. ${ }^{13}$

Komorbiditas juga merupakan hal yang signifikan berkaitan dengan mortalitas pasien COVID-19 pada penelitian ini. Hal yang sama ditemukan pada sebuah penelitian bahwa sebanyak 34 pasien dengan COVID-19 yang kritis ditemukan komorbiditas kronis, termasuk obesitas, hipertensi, diabetes, penyakit kardiovaskular, penyakit serebrovaskular, penyakit paru, penyakit ginjal, dan keganasan yang merupakan faktor risiko klinis yang dapat menyebabkan kondisi menjadi kritis terkait dengan COVID-19. Obesitas menjadi komorbiditas yang paling umum dan penyakit paru menjadi prediktif yang paling kuat. Komorbiditas yang kronis berkaitan dengan infeksi yang terjadi, seperti keadaan inflamasi yang lebih lama dan disfungsi imunitas bawaan dan adaptif yang mungkin menjadi penyebab utama dari klinis yang lebih buruk pada pasien yang terinfeksi SARS-CoV-2. ${ }^{14}$

Pada penelitian ini VR dan Vd/Vt merupakan variabel yang secara signifikan memiliki hubungan dengan mortalitas pada pasien COVID-19 dengan ARDS dapat dijadikan sebagai prediktor mortalitas dalam 24 jam pertama pasien terdiagnosis dan merupakan temuan yang utama penelitian ini. Penelitian sebelumnya pada tahun 2018 yang dilakukan untuk menentukan hubungan VR dengan Vd/ Vt pada pasien ARDS klasik didapatkan bahwa $\mathrm{Vd} / \mathrm{Vt}$ merupakan prediktor independen mortalitas pada sindrom gangguan pernapasan akut (ARDS). VR adalah indeks sederhana yang dapat dihitung menggunakan variabel pernapasan yang diukur secara rutin dan merupakan ukuran gangguan ventilasi. VR berkorelasi baik dengan Vd/Vt pada ARDS, dan nilai yang lebih tinggi pada awal dikaitkan dengan mortalitas yang lebih tinggi. Nilai VR dapat digunakan sebagai indeks yang sederhana gangguan ventilasi pada ARDS. ${ }^{10}$

Analisis Vd/Vt menunjukkan hubungan yang signifikan dengan mortalitas nilai ( $p$ 0,001 ) berdasar atas kurva ROC didapatkan cut-off point $\mathrm{Vd} / \mathrm{Vt}$ pada penelitian ini adalah 0,25 dengan AUC 0,85, sensitivitas 86\%, spesifisitas 85\%, RR 2,95 dan CI 95\%: 8,24-146,05. Berdasar atas hasil analisis ini dapat kita lihat Vd/Vt memiliki hubungan yang signifikan dalam menilai mortalitas pada pasien COVID-19 dengan ARDS. Data yang signifikan pada pasien ARDS memiliki perkiraan dead space fraction yang tinggi pada 4 jam pertama perjalanan ARDS. Temuan ini mengonfirmasi penelitian sebelumnya yang telah menunjukkan bahwa gangguan ventilasi dapat terjadi dalam beberapa jam setelah onset ARDS. Dead space adalah bagian dari setiap volume tidal yang tidak berkontribusi terhadap pembersihan $\mathrm{CO}_{2}$ dan mewakili indeks efisiensi fungsi paru yang baik secara global. Pada ARDS, peningkatan Vd/Vt dihasilkan dari 
peningkatan heterogenitas V/Q karena cedera kapiler oleh faktor trombotik dan inflamasi dengan obstruksi darah paru di sirkulasi paru dan mungkin beberapa derajat distensi berlebih oleh ventilasi mekanis. Status shunt dan curah jantung rendah dikenal sebagai penentu Vd/Vt tinggi. Namun, hal tersebut lebih disebabkan oleh gangguan perfusi daripada gangguan ventilasi itu sendiri. ${ }^{15-17}$

Analisis VR menunjukkan hubungan yang signifikan dengan mortalitas ( $p$ 0,001). Berdasarkan atas kurva ROC didapatkan cut-off point VR pada penelitian ini adalah 1,84 dengan AUC 0,82, sensitivitas 84,2\%; spesivisitas 85\%; RR 2,69 dan CI 95\%: 7,31 124,89 sehingga dari hasil analisis ini dapat kita lihat bahwa VR memiliki hubungan yang signifikan dalam menilai mortalitas pada pasien COVID-19 dengan ARDS. Hal ini sesuai dengan beberapa studi sebelumnya yang menunjukkan bahwa rasio VR merupakan prediktor mortalitas independen keparahan dan mortalitas ARDS. ${ }^{5,10}$ Ventilatory ratio (VR) adalah indeks gangguan efisiensi ventilasi yang sederhana dan memungkinkan penilaian yang cepat terhadap adekuat tidaknya ventilasi serta berkorelasi baik dengan dead space pada pasien dengan ARDS. ${ }^{18}$ Pada tahun 2018 dilakukan penelitian untuk menentukan hubungan VR dengan Vd/Vt pada pasien ARDS. Vd/Vt adalah prediktor independen mortalitas pada sindrom gangguan pernapasan akut (ARDS) jarang digunakan dalam praktik karena pengukuran dead space fraction oleh Enghoff menggunakan kantong douglas untuk mengukur $\mathrm{PECO}_{2} \cdot{ }^{19}$ Untuk itu diperlukan perhitungan estimasi dead space yang lebih praktis tanpa perlu penggunaan kantong douglas. Penelitian pada 170 pasien mengenai dead space, D-dimer, dan emboli pulmonal. Kline memodifikasi persamaan Bohr dengan menggunakan $\mathrm{ETCO}_{2}$ sebagai pengganti $\mathrm{PECO}_{2}{ }^{9}$ Namun, di daerah dengan fasilitas rumah sakit yang kurang memadai $\mathrm{ETCO}_{2}$ merupakan barang yang langka. Untuk itu, VR merupakan indeks sederhana yang dapat dihitung menggunakan variabel pernapasan yang diukur secara rutin dan merupakan ukuran dari gangguan ventilasi tanpa memerlukan piranti tambahan.

Pada penelitian ini ditemukan korelasi yang kuat antara VR dan Vd/Vt berdasar atas uji korelasi Spearman dengan koefisien korelasi $0,704(p<0,001)$. Halyang sama pada penelitian lain, VR telah diusulkan sebagai pengganti alternatif untuk Vd/Vt. VR yang mencakup prediksi ventilasi semenit dan estimasi $\mathrm{PaCO}_{2}$ telah dijelaskan dapat memantau efisiensi ventilasi dan secara independen terkait dengan mortalitas pada pasien ARDS. ${ }^{5}$ Pada penelitian sebelumnya, VR berkorelasi baik dengan Vd/ Vt pada ARDS dan nilai yang lebih tinggi pada awal dikaitkan dengan peningkatan risiko hasil yang merugikan. ${ }^{10,20}$

\section{Simpulan}

VR dan Vd/Vtterbukti dapat digunakan sebagai prediktor mortalitas pasien COVID-19 dengan ARDS dan keduanya mempunyai korelasi yang kuat. VR dapat menggantikan Vd/Vt.

\section{Daftar Pustaka}

1. Huang C, Wang Y, Li X, Ren L, Zhao J, Cao B, dkk. Clinical features of patients infected with 2019 novel coronavirus in Wuhan, China. Lancet. 2020;395(10223):497-506.

2. World Health Organization. Naming the coronavirus disease (COVID-19) and the virus that causes it, World Health Organization, (diunduh 5 April 2020). Tersedia dari: https://www. who.int/emergencies/diseases/novelcoronavirus-2019/technical-guidance/ naming-the-coronavirus-disease-(covid2019)-and-the-virus-that-causes-it.

3. Wang D, Hu B, Hu C, Zhu F, Liu X, Zhang J, dkk. Clinical characteristics of 138 hospitalized patients with 2019 novel coronavirus-infected pneumonia in Wuhan, China. JAMA. 2020;323(11):10619.

4. Wu C, Chen X, Cai Y, Xia J, Zhou X, Song Y, dkk. Risk factors associated with acute respiratory distress syndrome and death in patients with coronavirus disease 2019 pneumonia in Wuhan, China. JAMA Intern 
Med. 2020;180(7):934-43.

5. Quinteros-Morales L, Schultz MJ, Bringué J, Calfee CS, Camprubí M, Cremer OL, dkk. Estimated dead space fraction and the ventilatory ratio are associated with mortality in early ARDS. Ann Intens Care. 2019;9(1):128.

6. Nuckton T, Alonso J, Kallet R, Daniel B, Pittet J, Eisner M, dkk. Pulmonary dead-space fraction as a risk factor for death in the acute respiratory distress syndrome. New Eng J Med. 2002;346(17):1281-6.

7. Liu X, Liu X, Xu Y, Xu Z, Huang Y, Chen S, dkk. Ventilatory ratio in hypercapnic mechanically ventilated patients with covid-19-associated acute respiratory distress syndrome. Am J Respirat Crit Care Med. 2020;201(10):1297-9.

8. Bohr C. Uber die Lungeatmung [in German]. Skand Arch Physiol. 1891;(2):236-8.

9. Kline J, Meek S, Boudrow D, Warner D, Colucciello $\mathrm{S}$. Use of the alveolar dead space fraction (vd/vt) and plasma d-dimers to exclude acute pulmonary embolism in ambulatory patients. Academic Emerg Med. 1997;4(9):856-63.

10. Sinha P, Calfee CS, Beitler JR, Soni N, Ho K, Matthay MA, dkk. Physiologic analysis and clinical performance of the ventilatory ratio in acute respiratory distress syndrome. Am J Respirat Crit Care Med. 2019;199(3):333-41.

11. Gibson PG, Qin L, Puah SH. COVID-19 acute respiratory distress syndrome (ARDS): clinical features and differences from typical pre-COVID-19 ARDS. Med J Australia. 2020;213(2):54-6.e1.

12. Bellani G, Laffey JG, Pham T, Fan E, Brochard L, Esteban A, dkk. LUNG SAFE investigators, \& ESICM trials group; epidemiology, patterns of care, and mortality for patients with acute respiratory distress syndrome in intensive care units in 50 countries. JAMA. 2016;315(8):788-800.

13. Huang $Y$, Lu Y, Huang YM, Wang M, Ling W, Sui Y, dkk. Obesity in patients with COVID-19: a systematic review and meta-analysis. Metabolism: Clin Exper. 2020;113: 154378.

14. Yue Z, Qing Y, Jingwei C, Bingzi D, Wenshan, Lv, Liyan S, dkk. Comorbidities and the risk of severe or fatal outcomes associated with coronavirus disease. A systematic review and meta-analysis, Intern J Infect Dis. 2019;99:47-56,

15. Petersson J, Glenny R. Gas exchange and ventilation-perfusion relationships in the lung. Euro Respirat J. 2014;44(4):102341.

16. Rodger M. Steady-state end-tidal alveolar dead space measure and d-dimer. Chest. 2010;121(4):1373-4.

17. Zhang YJ, Gao XJ, Li ZB, Wang ZY, Feng QS, Yin CF, dkk. Comparison of the pulmonary dead-space fraction derived from ventilator volumetric capnography and a validated equation in the survival prediction of patients with acute respiratory distress syndrome. Chinese J Traumatol Zhonghua Chuang Shang Za Zhi. 2016;19(3):141-5.

18. Sinha P, Fauvel NJ, Singh S, Soni N. Ventilatory ratio: a simple bedside measure of ventilation. Br J Anaesth. 2009;102(5): 692-7.

19. Enghoff, H. Volumen inefficax. Bemerkungen zur Frage des sch€adlichen Raumes. Uppsala L€akareforen Forhandl. 1938;44:191-218.

20. Sinha P,Sanders RD, Soni N,Vukoja MK, Gajic 0 . Acute respiratory distress syndrome: the prognostic value of ventilatory ratio--a simple bedside tool to monitor ventilatory efficiency. Am J Respirat Crit Care Med. 2013;187(10):1150-3. 